\title{
Language Acquisition: The Influential Factors And Its Connection With Age
}

\author{
Dony Marzuki
}

State Polytechnic of Padang

E-mail: bugepnp@yahoo.co.id

\begin{abstract}
The term of language acquisition often leads to a misinterpretation when it deals with English learning. However, there is one distinct point that might be pointed out about language acquisition which differentiates it with the general language learning. Language acquisition is the process of acquire language while language learning is the process of learning the language. This article is meant to give a perspective about language acquisition, factors that influence the acquisition and also the connection of language acquisition with age.
\end{abstract}

Keywords-Language acquisition, first language acquisition and second language acquisition

\section{INTRODUCTION}

Learning a language is different from learning other skills or knowledge because of the unique status owned by a language. One can learn a language to understand how the language works. However, in order to be able to use the language, one must also acquire it (Krasen, 1981). The process of this acquiring language is then known as language acquisition. Wilson (2000) states that; "language acquisition is a subconscious process to acquire a language. In this process, language acquirers are not consciously aware of the grammatical rules of the language, but rather developing a "feel" for correctness". Krashen mentions that language acquisition is determined as the process of 'picking-up' a language (Krashen, 1981 cited in Wilson, 2000). In other words, language acquisition can be defined as the way people learn about a language and only focus on the way of using it for communication purposes rather than the grammar in the language.

There are two kinds of language acquisition already known which are also different each other depend on the learners and the place they learn or acquire the language. Those are the first and second language acquisitions. The first language acquisition is about acquiring first language in one's life in where it usually starts at younger age or childhood (Cook, 1969). The first language must be a mother tongue that is heard and spoken for the first time at the early stage of a child begins to speak. Therefore, most of the learners of first language are children or even infants. On the other hand, second language acquisition deals with acquiring other or additional language than the first language, often known as second language, and most of the learners are older children or people (Cook, 1969). Both of them are also known as disciplines in language teaching and learning that deals with how people learning languages.

\section{PAge LAyout}

First and second language acquisition have some differences that can be caused by factors as can be found in Cook, Long, \& McDonough (1979):

\section{A. Age}


Age plays the most significant role in differentiating first and second language acquisition. Learners of first language are mostly children or infants therefore the way they acquire the first language is influenced by their mental condition and consciousness as learners who are not afraid of making mistake. Children usually show no anxiety and stick only to the meaning of language they use as the only purpose of their learning. Meanwhile, second language is usually learned by more mature people with all their consciousness in learning to have additional language for many purposes such as expanding social relationship, studying abroad or in other country, or for getting a job. Children also develop clear intuitions about correctness that will help them learn better while second language learners are often unable to form clear grammaticality judgments that may be a big obstacle in learning. Children usually acquire their first language naturally, while adults, as stated to be in postcritical period already, do not naturally acquire their second language, as a number of fundamental differences appear in their rationale towards learning. More discussion about age and second language acquisition can be found in other section of this article.

\section{B. Degree of Acquisition}

There has been a major agreement in the world that one will come to a perfect mastery of the language, as they will be the native, when learning first language. Even there is success guaranteed for the learners. This condition is very unlikely to happen in second language learning because the degree of success depends on many things such as motivation, support, and environment. So, complete success in acquiring second language is rarely found as the degree of acquisition is low.

\section{Competency}

The competency needed in the first and second language acquisition is also different. Learners need to acquire perfect accuracy in target language when dealing with first language acquisition; while in second language acquisition the competence could only be focused on fluency in using target language. Accuracy is not the main target in second language because users or learners merely use the language for communication purpose or the function of language which are not really stressed on language form.

\section{Instruction}

Almost all first language acquisitions happen in informal situation like at home. Usually, the process of acquiring the language starts when a child tries to say something that they think similar to what they have heard in order to get everything they need from parents or other family members. Here, parents provide very little in the way of language instruction to the child. They do not actually teach their children to speak, they only correct falsehoods but not erroneous grammars. Very different situation occurs with second language acquisition that mostly takes place in formal setting such as school or classroom. This setting indeed requires instruction and even teacher to make the instruction works. Here, instruction is helpful and necessary for acquiring the second language.

\section{E. Affective Factor}

As first language acquisition mostly performed by children, and then there will be no affective factor involved in the process. On contrary, second language acquisition that performed by more varied and mature people needs affective factors that play a major role in determining level of proficiency.

The first language children mostly acquire language in different settings with different exposure to language than the second language learners and they are at different stages of mental and social maturity (Cook, 1969). The differences indeed make the acquisition of first language different from the second language wherever it occurs.

\section{Age AND SeCOND LANGUAGE ACQUisition}

Discussion on effects of age toward Second Language Acquisition has been the most debatable one comparing to other variables that influence the acquisition such as motivation, learning styles, personality, sex, aptitude, and attitude. Many studies and researches have been conducting in order to get a better understanding about how age affects this Second Language Acquisition (SLA).

\section{A. Second Language Acquisition}

As mention above, second language acquisition is the process to acquire other or additional language than the first language, often known as second language, and most of the learners are older children or people. As one discipline in 
language teaching and learning, the focus of SLA is language learning and use in where learners must communicate and interact in the L2 (second language) or target language in everyday life. The acquisition of this L2 involves code switching or the ability to switch from one language (L1) to another (L2) in constructing sentence or communicating. A person who watches movies in his or her second language cannot acquire the language because there is no interaction and code switching in it. Strzepek (2004) states that actual acquisition of an L2 occurs when an individual is able to code switch in his or her mind without taking extra time and without mixing up or confusing the two different languages. In other words, SLA happens when the learner can give up code switching and start to think in the target language”. So, one with L2 acquisition must be able to use the language along with his or her L1 although he or she does not perceive native-like ability for the L2.

\section{B. How does age affect SLA?}

Discussions and studies about effects of age on SLA have been widely conducted until today, and yet the real answer remains uncertain. The discussions involve two major players; younger and older learners. One major finding from studies about these two players is that young learners are better in learning language in long term while older learner is better in short time. Snow \& Hoefnagel-Hoehle (1978) in their study involving children and adults English speakers who study Dutch language conclude that older learners are better than younger learners in terms of rate of acquisition in the initial stage of SLA. The study reveals that within three months, older learners outperform children in the test given and both groups have the same result after six months of the study. Another study conducted by GarciaLecumberry \& Gallardo (2003) toward a group of children between 4 to 11 years old Spanish L1 who study English shows that older children have better result and understanding with the English.

Similar studies have come up with the same opinion. Those studies reveal that older people are able to get more comprehensible input because they have better cognitive skill and better memory. They have greater ability to beat the silent period and perform using structures that they have never seen or acquired. Older people also have everything helpful in learning language suach as better knowledge, experience and background information of the world which make the input more comprehensible to them. Meanwhile, children usually acquire competence in L2 over the long run. They usually will be good in pronunciation, accent and some aspects in phonology for L2 while older people have advantage in grammar. Usually, children will find it difficult to comprehend grammatical structures because they have less pragmatic skills and memory (Johnson and Newport, 1989; and Flege, Yeni-Komshian and Liu, 1999).

\section{Critical Period Hypothesis (CPH)}

The study of correlation between age and SLA cannot be separated from Eric Lenneberg theory about critical period hypothesis. According to Lenneberg, "automatic acquisition from mere exposure to a given language seems to disappear after puberty, and foreign languages have to be taught and learned through a conscious and laboured effort” (1967, p. 176). It means that children have better ability to learn language than teenagers or adult because their brains are at the best period to do so. However, the existence of this critical period is still in controversy. Many researches in $\mathrm{CPH}$ have conducted and most of them show contradictory evidences. Some are supporting the $\mathrm{CPH}$ while other reject it. Krashen's Input Hypothesis is one of supports known for CPH. According to Krashen, a critical period does indeed exist; since the hypothesis assumes not only that L2 acquisition is similar in nature to L1 acquisition, but also that this is the case for learners of any age. Although that Krashen's theories are claimed to be fault in any case, their influence in the field of second language teaching cannot be denied.

Different opinion toward CPH can be seen from several studies. For example, Hyltenstam \& Abrahamsson (2000) who mention that CPH must be interpreted as younger equals better in terms of eventual outcome hypothesis. Nowadays, studies on connection between age and SLA are mainly focused on non-native speaker's abilities and the proficiency to reach native-like. For example, the study conducted by Ioup, Boustagui, El Tigi \& Moselle's (1994) about successful adult learners of SLA in a naturalistic environment, and Nikolov, Marianne \& Iral's (2000) who study adult learners 
of Hungarian and English. Both of these studies try to find out whether learners will still have native-like proficiency when they have passed the critical period. The results are still in controversy that there are no clear conclusion about who are better in SLA as both adults and children show different responds in various studies. Sometimes adults are considered better with some conditions while children could also be better under different treatment of studies. Ehrman \& Oxford (1995) from their study conclude that, "younger learners are more likely to attain fluency and native-like pronunciation, while older learners have an advantage in understanding the grammatical system and in bringing greater 'world knowledge' to the language learning context".

\section{CONCLUSIONS}

There are two kinds of language acquisition known in language learning, the first language acquisition and the second language acquisition. Language acquisition is proved to be influenced by many factors such as the degree of acquisition, instruction, competency, some affective factors, and offcourse age. Age is the main factor that gets many attentions from linguist and language researchers to acquire more evidence about its influence. The discussions about effect of age on SLA have resulted in different opinions. Some say that age has significant factor while other claim that it gives nothing. However, both groups of age, children and adult, who are the objects of studies in this field, have their own advantages. Children is good in anything dealing with sound repetition like pronunciation, while adult is better in grammatical issue. So, we cannot say that one group is better than the other in SLA. This would make the debate over the Critical Period Hypothesis (CPH) as a central issue in SLTL.

\section{REFERENCES}

[1] Cook, V.J. (1969). The Analogy between First and Second Language Learning. IRAL VII(3), 207-216.

[2] Cook, V.J., Long, J., \& McDonough, S. (1979), 'First and second language learning', in G.E. Perren (ed.) The Mother Tongue and Other Languages in Education, CILTR, 7-22.

[3] Ehrman, M. E., \& Oxford, R. L. (1995). Cognition Plus: Correlates of Language Learning Success. The Modern Language Journal, 79, i, 67-89.

[4] Flege, J. E., Yeni-Komshian, G.H., \& Liu, S. (1999). Age Constraints on Second-Language Acquisition. Journal of Memory and Language, 41, 78-104.

[5] Garcia Lecumberri, M. L. \& F. Gallardo. 2003: English FL sounds in school learners of different ages, in M. D. P. Garcia Mayo and M. L. Garcia Lecumberri, eds. Age and the acquisition of English as a foreign language. Clevedon: Multilingual Matters. pp. 115-135.

[6] Hakuta, K., Bialystok, E., Wiley, E. (2003). Critical Evidence: A Test of the Critical Period Hypothesis for Second-Language Acquisition. Psychological Science, 14 (1), 31-38.

[7] Hyltenstam, K., \& Abrahamsson, N. (2000). Who can become native-like in a second language? All, some, or none? Studia Linguistica. 54 (2), 150-166.

[8] Ioup, G., Boustagui, E., El Tigi, M., \& Moselle, M. (1994) Reexamining the Critical Period Hypothesis: A Case Study of Successful Adult SLA in a Naturalistic Environment. SLA, 16, 73-98.

[9] Johnson, J. S., \& Newport, E. L. (1989). Critical Period effects in second language learning: the influence of maturational on the acquisition of English as a second language. Cognitive Psychology, 12, 60-99.

[10] Krashen, S. D. (1985). The input hypothesis: Issues and implications. London \& New York: Longman.

[11] Lenneberg, E. H. 1967: Biological foundations of language. New York: John Wiley.

[12] Nikolov, Marianne, \& Iral. (2000). The Critical Period Hypothesis Reconsidered: Successful Adult Learners of Hungarian and English. International Review of Applied Linguistics in Language Teaching, 0019-042X 38 (2).

[13] Snow, C. E. \& Hoefnagel-Hoehle. M. 1978: The critical period for language acquisition: evidence from second language learning. Child Development 49, 1114-1128.

[14] Wilson, Reid. (2000). A Summary of Stephen Krashen's "Principles and Practice in Second Language Acquisition" viewed on October 24th, 2011 in http://www.languageimpact.com/articles/rw/ krashenbk.htm 